\title{
Variety of Aspects of Researches of Graphic Activity as Pedagogical Problem
}

\author{
Nikolai Yevgenyevich Petrov \\ Kazan (Volga Region) Federal University, Kazan \\ E-mail: petrovkfu@mail.ru
}

\section{Doi:10.5901/mjss.2015.v6n1s2p96}

\begin{abstract}
The paper concerns the works of the educational specialists on the problem of teaching art to children and youth. It analyses the works of A.S. Akhmanov, F.I. Schmidt, A.B. Bakushinsky and others. The article gives the retrospective review of the pedagogical works concerning teaching art to children. It was studied in detail by a great number of educators and methodologists, each of whom revealed one side of it. As a result, the artistic activity has been thoroughly studied and characterized since the 1920s. Almost all of its many aspects were touched and studied. The researchers developed different methods which dealt with space coordination, the peculiarities of the perception of various kinds of art and other aspects of art activity.
\end{abstract}

Keywords: abilities; art; children; creativity; pedagogy

\section{Introduction}

The Russian pedagogical science focused its attention on the all-round and significant researches in the sphere of art in the 20s of the XX c. Based on the method of teaching architectural composition developed by N.A. Ladovsky, N.V. Dokuchaev and V.F. Krinsky, the laboratory of Higher Art and Technical Studios (the VKHUTEMAS) studied the abilities of space coordination and orientation, space images, imagination and construction as well as eye sketch (KhanMagomedov 1982). The questions of studying the peculiarities of art, architecture and sculpture perception were studied thoroughly by the laboratory of the State Academy of Arts.

The main idea expressed in the works by A.S. Akhmanov, N.N. Volkov, A.N. Gabrichevsky. A.N. Smirnov, B.M. Teplov, etc. was the idea that 'culture and, especially, taking up art are the most important factors in forming the personality. They create culture awareness and self-consciousness, reveal and develop abilities (Martsynkovskaya \& Poleva, 1998).

\section{Methodology}

The first researcher to reveal the potential of art activity as a means of creative development was F.I. Schmidt (1923). The basis of his concept of teaching children to draw was a strict phased training. According to F.I. Schmidt, the development of children's art creativity copies the stages of art development.

As the image thinking goes ahead of logical one in ontogeny, it is necessary to start with learning 'knowledgeimages' and creating the conditions for children to get this knowledge in the process of accumulating personal experience of live impressions from environment and human activities.

The development of emotional, associative thinking is realized through direct exposure to art, but not only through drilling and improving drawing techniques. This process considers the development of imagination and skills to express inner emotions through images. The role of a teacher is to show the ways of solving art problems taking into account that the problems are not technical but psychological in character. A child should learn how to perceive images as the most intimate, personal and valuable (Vygotsky, 1987).

The most important principle of the development in art, according to A.B. Bakushinsky (1925), is applying art means. Among them he singles out rhythm as a beginning of arrangement in art imagination which helps to work with the space of a sheet and colour as one of the brightest artistic-expressive means. Drawing is also in need of motional and visual experience of a student.

The researchers of children's art activity, such as S.N. Shabalin, S.V. Mukhin, Z.M. Boguslavskaya, K.I. 
Veresotskaya, E.A. Ferapontova, S.G. Yakobson, studied the peculiarities of visual perception of colour and form by children. The development of perception in art was analysed by A.F. Minkova, G.S. Filipyuk, etc. The age peculiarities of perception and imagination were revealed by N.S. Lukin, M.A. Muzafarov, V.G. Stepanov.

S.G. Kaplanov (1948) conducted a research of the V.I. Surikov's art. According to the author, the object of such analysis should be the processes of perception, creative thinking and imagination.

A great contribution to understanding the peculiarity of art activity as an activity which shows and develops creative abilities of a person, special artistic skills, was made by I.N. Volkova, E.I. Ignatyeva, V.I. Kirienko.

Educational art activity, especially life drawing, is considered by E.I. Ignatyev as a basis for the development of art creativity, the success of which he connects with the productive work of imagination, noting that 'for a full-rate work 'on imagination' it is necessary to learn the ways of drawing certain objects in life' (Psychology of drawing 1954).

N.N. Volkov thoroughly studies the problems of perception and imagination from the point of view of professional art drawing. He develops the problem of 'feedbacks', i.e. the influence of perception, which appears in the process of drawing images, on the process of art activity.

The methodological grounding for further researches of art activity from the point of view of active approach was developed in the works of S.L. Rubinstein, A.N. Leontyev, B.M. Teplov, B.F. Lomov.

The teachers-methodologists use the term 'educational artistic activity', which includes learning the historicallytested artistic tools (V.P. Zinchenko, A.A. Melik-Pashev, Z.I. Novlyanskaya, N.N. Rostovtsev, etc.).

In the paradigm of the active approach, the artistic activity is considered by the researchers (G.V. Labunskaya, T.S. Komarova, N.P. Sakulina, E.A. Flerina, etc.) as an artistic-creative activity, which is directed not only to the reflection of the impressions taken from life, but the expression of a personal attitude to the painted objects as a factor of the development of aesthetic perception, education through artistic creativity as well (Komarova, 1990).

The authors underline that 'one, even comprehensive perception is not enough for creating a drawing. To express the ideas on canvas, it is necessary to teach technical skills, artistic execution, skills for using pencil and other tools' (Sakulina 1965). Aiming to develop creativity in students, it is necessary to have certain knowledge and skills, i.e. directive teaching on using means of creating artistic image.

T.A. Solovyova (1994) in her research notices that 'the main aim of artistic activity is the development of aesthetic consciousness in children'. According to the author, aesthetic assessment of reality is the basis for artistic abilities.

E.A. Flerina says that 'accumulation of creative tasks is directly-proportional to consolidation of knowledge and improvement of educational achievements, i.e. if any result in drawing or modelling is fixed, the child can develop more ideas, and vice versa (Lepskaya 1999).

The course of artistic education 'Creativity and expression' by the Italian authors M.K. Prette and A. Kapaldo (1981) is well-known in Russia and abroad. The developers of this course offer a range of practical tasks, connected to studying different kinds and genres of art, artistic materials and ways of their application.

Some authors (E.Ya. Basin, V.P. Zinchenko, A.A. Melik-Pashaev, V.S. Mukhina) single out the stages of studying artistic activity: pre-art, sign art, iconic art (Nikiforova 1972).

E. Ya. Basin specifies the following stages in establishing artistic activity:

- studying other works;

- own practical activity which starts with copying the samples;

- esthetic direction, which creates the core of artistic personality;

- constant hard work.

S.L. Rubinstein (1982) in his research works noted the impact of artistic activity on perception of the painter. 'The process of perception of reality by the painter and the process of drawing couldn't be separated from each other. Not only creativity depends on perception, but perception itself depends on representation; it follows the terms of representation and formed in correspondence with them'.

In XIX century P.P. Chistyakov pointed at the connection between artistic activity and thinking, saying that 'to draw means to think' (Kuzin, 1974). V.S. Kuzin represented artistic art as a process of consequent solution to some mental processes, in this way connecting artistic process with active work of painter's thinking process.

O.I. Nikiforova (1972) notices the essential difference of the ways of mental activity between those 'who is in search of the object and those who creates typical image on canvas'. The first group 'analyses the object, single out features and generalize them.' The second group 'analyses the objects and draw'.

Drawing, according to N.G. Salmina (1984), teaches 'to make an analysis of defining the object, identify it in drawing, single out certain features in object and encourage the development of an intellect'. 


\section{Conclusions}

The general review of the research works devoted to artistic activity as a pedagogical issue showed that it was studied by a great number of educators and methodologists, each of whom revealed one side of it. As a result, to our mind, the artistic activity has been thoroughly studied and characterized since the 20 s of XX century. Almost all its aspects were touched and studied; the results were given in our retrospective review.

\section{References}

Bakushinsky, A.V. (1925). Artistic creativity and education: The research on the basis of space arts. Moscow: Novaya Moskva.

Kaplanov, S.G. (1948). Psychological analysis of the Surikov's work on 'The boyar Morozova'. Moscow: Novaya Moskva.

Khan-Magomedov, S.O. (1982). Psycho-analytical method of N. Ladovsky as a basis for propaedeutic subject 'Interspace' in VHUTEMAS and VHUTEIN. Technical esthetics, 4, 27-32.

Komarova T.S. (1990). The development of art activity skills. Moscow: Pravda.

Kuzin V.S. (1974). Psychology. Moscow: Vysshaya shkola.

Lepskaya N.A. (1999). Computer technologies in developing artistic skills of students at schools (Unpublished candidate dissertation). Moscow State University.

Martsynkovskaya, T.D., \& Poleva, N.S. (1998). The role of State Academy of Arts in the research work of B.M. Teplov. Issues of Psychology, 4, 94-102.

Melik-Pashaev, A.A. (1981). The pedagogy of art and artistic skills. Moscow: Znaniye.

Nikiforova, O.I. (1972). The research on psychology of artistic creativity. Moscow: Pravda.

Prette, M.K. \& Kopaldo, A. (1981). Creativity and expression. A course of artistic education. Sovetsky Khudozhnik, 1, 5-6.

Psychology of drawing and painting (1954). Moscow: Novaya Moskva.

Rubinstein, S.L. (1982). The problems of skills and the questions of psychological theory. Psychology of individual differences. Moscow: Vysshaya shkola.

Sakulina, N.P. (1965). Drawing in preschool age. Moscow: Prosveshcheniye.

Salmina, N.G. (1988). The sign and a symbol in teaching. Moscow: Prosveshcheniye.

Schmidt, F.I. (1923). Art as a teaching subject. Kharkov: Osnova.

Solovyeva, T.A. (1994). The peculiarities of showing content-related, operational and motivational components of educational art activity of primary school children. Arkhangelsk: Pravda Severa.

Vygotsky, L.S. (1987). Psychology of art. Moscow: Pedagogika. 